\title{
Perceptions of Special Education Teachers on the Internal Efficacy of Their Institutions: A Comparative Study
}

\author{
Muhammad Zahid ${ }^{\text {a }}$, Samina Ashraf ${ }^{\text {b }}$ \\ ${ }^{a}$ Ph. D Scholar, Department of Special Education, University of the Punjab, Lahore, Pakistan \\ Email: mohzahidch@gmail.com \\ ${ }^{\mathrm{b}}$ Ph. D \&Post Doc., Department of Special Education, University of the Punjab, Lahore, Pakistan \\ Email: samina.dse@pu.edu.pk
}

\begin{tabular}{l}
\hline ARTICLE DETAILS \\
\hline History: \\
Accepted 28 Nov 2020 \\
Available Online 31 Dec 2020 \\
\hline Keywords: \\
Educational Institutions, Internal \\
Efficacy, Teachers' Perception
\end{tabular}

ABSTRACT

Special education institutions are providing services to meet the unique needs of special students. Internal efficacy of any institution determines its effectiveness in terms of its outcomes. The current study was designed to explore the internal efficacy of special education institutions. The population of the study comprised of teachers teaching in the special education institution of the Lahore city. Sample of the study consisted of 200 teachers randomly selected from public and private sector special education institutions, currently performing their duties in the Lahore

JEL Classification:

I23, A2O city. The study was quantitative in its nature conducting with descriptive research design. A standardized questionnaire was used to collect the data from the teachers after getting permission from its author. Initially, the questionnaire was piloted on a small number of participants to ensure its reliability. That was confirmed through

DOI: $10.47067 /$ reads.v6i4.280 Cronbach alpha (.750). After ensuring ethical considerations, researchers collected data by themselves from the teachers. The data were analyzed using SPSS. Results of independent sample t-test show the statistically significant difference between the public and private sector institutions' internal efficacy. The internal efficacy of public sector special education institutions was better as compared to private sector special education institutions. Majority of the special education teachers serving in public sector institutes ranked the institutional communication, working environment, quality of education and professional support as major determined of internal efficacy of their institutions. The study has recommended that the private sector special education institutions need to enhance their internal efficacy.

(C) 2020 The authors. Published by SPCRD Global Publishing. This is an open access article under the Creative Commons Attribution-

NonCommercial 4.0

Corresponding author's email address: mohzahidch@gmail.com

\section{Introduction}

The internal efficacy of educational institutions is determined through their maximum use of resources in producing its output. It is actually putting all efforts to strengthen the school 


\section{Review of Economics and Development Studies, Vol. 6 (4) 2020, $811-820$}

effectiveness(Yunus, 2014).This processes that take place in any educational institution matters for students' academic and social outcomes (Ramberg, Laftman, Almquist, \& Modin, 2019) and helps in determining that institution's internal efficacy. Teachers and students self-efficacy influence the internal efficacy of academic institutions too. As according to Galos and Aldridge (2020) the institutional environment is connected with students' efficacy that is also related with school efficacy and effectiveness. Institutions are facing problems to tradeoff between the institutional efficacy and enhancement of education at all levels. Particularly ensuring the availability of maximum resources focusing on institutional demands, teachers' professional development, institutions' better and vibrant environment, students' reward system and better learning outcomes by the government (Hassan, 2019; Ahmad, Rauf, Imdadullah, \& Zeb, 2012; Faize, 2011; Iqbal \& Mahmood, 2000,).

According to Adeyemi (2012) internal efficacy is an association between input and output of education system. Input of institutions consist of teachers, schools' buildings, classrooms, furniture, chairs, whiteboard, students' yearly cost and the entire resources available in institutions to obtained required objectives (Olubor, 2004) whereas output means number of students that become graduates from prescribed institution after investment. Dwaikat (2020) has elaborated this association as an indicator of quality and effectiveness of academic institution.

The schools principals play main role in shaping the learning environment in school, which is important for students learning and teachers' performance (Skaalvik, 2020). They have the potential to assign task and responsibilities focusing their regular needs. They are responsible to shape their institutional environment while focusing present day schools' reforms. Learning environment of schools make students more dynamic in the achievement of their educational goals. Students remained indulged in learning activities, understanding knowledge and catch teachers' strategies (Akinloye \& Adu, 2015). It enhances students better achievements, teaching manner of teachers and improves the administration style of school heads as well (Dansey, 2004). Students' learning environment should be obstacles free to enhance their concentrations and enable them to focus on their conceptual understanding. Focusing the internal efficacy of institutions, the enrollment of students and class size is considered as an important factor. Standardized class size and number of students attracts teachers towards imparting more knowledge and better working of institutions (Adeyemi, 2008). Globally in Turkey, Norway, Netherland and New Zealand the number of students in one class is 20, whereas the student teacher ratio in Japan, US, USA, Canada and Ireland are 1-15/20 students. Same is in the case of France, Australia, Sweden, Italy and Belgium is 15 students in single class (Adeyemi, 2008).

The literature on internal efficacy has reported internal efficacy of educational institutions as key aspect that helps stakeholders including students, teachers, parents and head teachers towards better growth (Yunus, 2014).Some previous researches have elaborated the perceptions of teachers for instance the study conducted by Davis and Ellison (1997) in UK to find out perceptions of teaches on the internal efficacy of different schools. They collected the data from respondents by using self-developed questionnaire consisted of 5 -factors including communications, work environment, professional environment, quality of education, professional support and administrator/governor mode. The respondents were provided 3-point Likert scale to respond on each item. Results of descriptive analysis shows that participants' perception on professional environment was $58.92 \%$, professional support $54.59 \%$, communication $49.19 \%$, working environment $48.65 \%$, governors $37.84 \%$, and quality of education $35.14 \%$ and have fewer perceptions on general items that $32.43 \%$. Adeyemi (2014) found the influence of schools' variables like locality, formation year and class size on institutional internal efficacy i.e., number of pass, fail and repeater graduate students. He administered self-constructed questionnaire among respondents after ensuring content validity and reliability. Results of Pearson 


\section{Review of Economics and Development Studies, Vol. 6 (4) 2020, 811 - 820}

Product Moment Correlation ( $r$ ) showed significant moderate correlation between schools' variables and internal efficacy $(r=.461, n=482, p<.05)$. Furthermore, results of regression analysis declared that teachers' qualification affect $62.78 \%$, teaching experience $61.43 \%$, class size $25.94 \%$, student-teacher ratio $46.27 \%$, schools' locality $35.74 \%$ and school size affect $25.94 \%$ on institutional internal efficacy.

Pakistan is running its public sector education since independence that are divided in general and special institutions. Concern of current research deals with the special education institutions working in District Lahore. In the era of 1958, National Education Commission, recommended to train teachers to fulfill needs of handicapped students (Government of Pakistan, 1959). Necessary arrangements were made for special students through inaugurating special institutions. The prominent institutions of Lahore were bound to admit students without references regarding their social, financial, educational and special backgrounds. Meanwhile the United Nations announced 1983-1992 as "Decade of the Disabled" which driven Pakistani Stakeholders minds to formulate and implement policies for the special students (Government of Pakistan, 1986a). In this connection, first policy for disable persons was structured and given the name of "National Policy for Rehabilitation of the Disabled" in December, 1986(Government of Pakistan, 1986). Policies makers classify special students in categories visually impaired, hearing impaired, physically disabled and multiple disabled after conducting survey in federal territory. Furthermore, stakeholders came to know that the number of students with special needs is gradually increasing. Finally it was reported in policy to proposed financial allowances for disable students through legislative support (Government of Pakistan, 1999). Later on National Policy for Persons with Disabilities, 2002 was put forwarded for public and private special educational institutions (Government of Pakistan, 2002). Special emphasis has been given on infrastructure, physical facilities, teachers' training and remedies for special students without any discrimination on the basis of gender, class, faith etc.

As the above discussion has shown that institutions' internal efficacy plays significant role in students' learning and in acquiring better educational performance. Being one of the important component of internal efficacy, the purpose of this study was to explore the perceptions of special education teachers serving in the public and private sector institutions on the internal efficacy of their respective institutions.

The objectives of the research were to

- Know the perceptions of special education teachers regarding the determinants of internal efficacy of public and private sector special education institution in Lahore.

- Find out difference between the internal efficacy of public and private sector special education institutions.

Following research questions were addressed in this study

1. What are the perceptions of special education teachers serving in public and private sector institutions regarding the determinants of their schools' internal efficacy?

2. Is there any difference between the internal efficacy of public and private sector special education institutions?

3. Do the differences between internal efficacy of public and private sector schools exists in all determining factors of special education institutions' internal efficacy?

\section{Research Methodology}

Research methodology deals with systematic procedures applied in research to reach the conclusion. Application of good research methodology provides scientific and sound findings (Bless \& 
Review of Economics and Development Studies, Vol. 6 (4) 2020, 811 - 820

Higson-Smith, 2000; Bryman, 2012). The study conducted by applying descriptive research design. In descriptive research nothing is manipulated and without changing the environment information is collected. The information is obtained concerning the current status (what exists) of the problem. The survey method was used to collect the data from the teachers (Yasmin, Nadeem, Siddique \& Ali, 2020).

\subsection{Population and sample of the study}

Population refers to entire respondents targeted for collect information including participants' geographical location, profession, gender and educational concerns (Cohen \& Duun, 2011; Hassan \& Akbar, 2020). Population of current study consisted of all teachers working in 15 public and 40 private sector special education institutions of District Lahore of the Punjab.

Sample is representative part that is being selected from entire population (Peat et al., 2002) that has complete properties of populations (Creswell, 2014). The sample of current study consisted of 200 teachers; randomly selected from public and private special institutions.

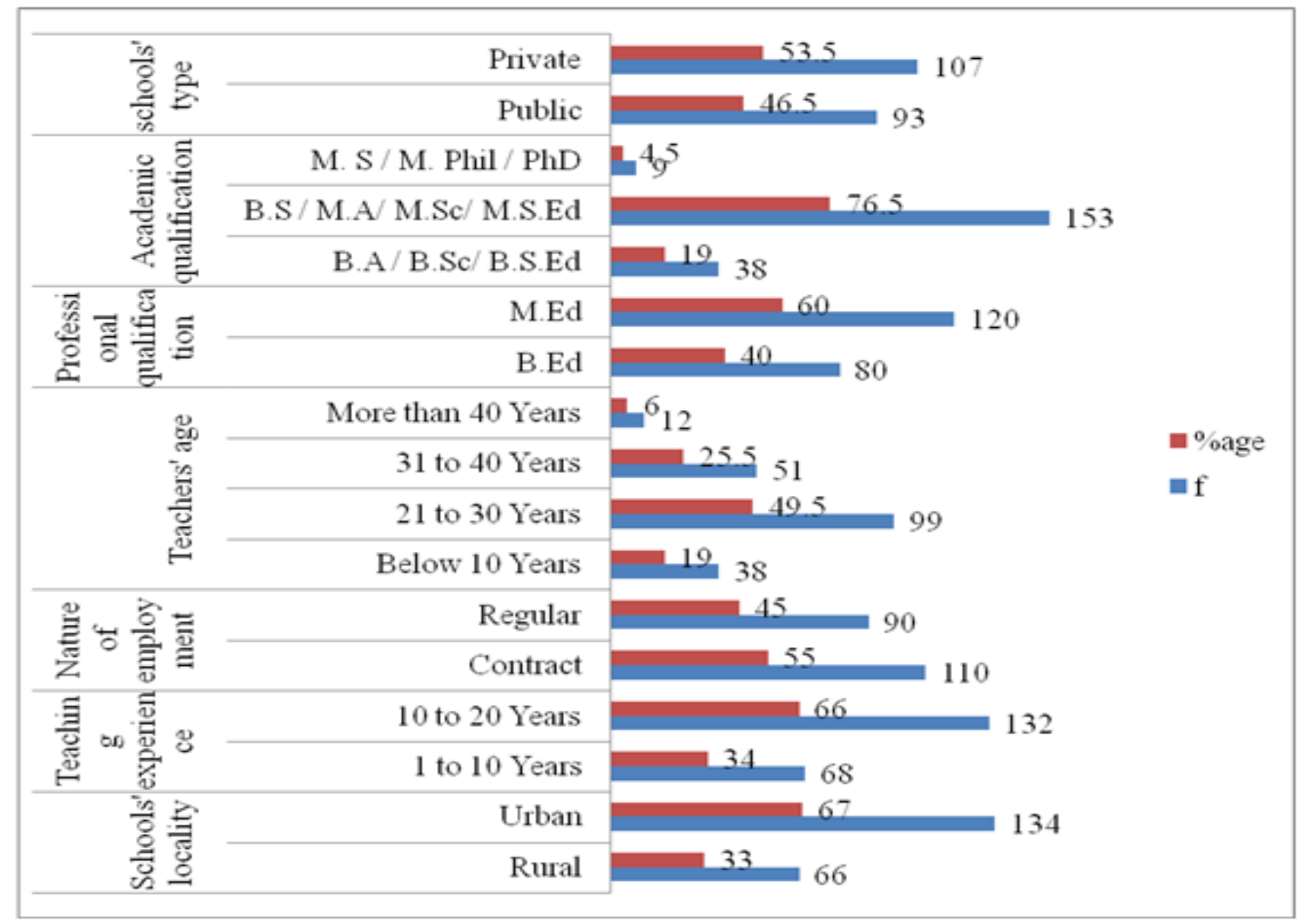

Figure.No.1: Demographics of the teachers taken as sample of this study

The above table showing the demographics of the teachers taken for this study. Table shows that majority of the teachers belongs to private sector schools. The qualification of majority teachers was M.A. /M. Sc. and having job experience from 10 to 20 years. The age of the majority teachers was from 21 to 30 years.

\subsection{Instrumentations}

Questionnaire is an important tool that help the researchers to obtain required information on the study (Khan, Hussain, Hussain, \& Khan, 2020). Instrument of this study was a questionnaire 
Review of Economics and Development Studies, Vol. 6 (4) 2020, 811 - 820

adopted from Davies and Ellison (1997) after getting their permission. The questionnaire consisted of two parts: part A having 30-items based on three points Likert type options i.e., yes, no and not sure whereas Part B consisted of 5-factors including communication (5 items), working environment (5 items), professional environment (5 items), quality of education (6 items), professional support (5 items), governors (3 items) and general consist of 1-item.

\subsection{Pilot Testing}

Questionnaire was piloted on small number of the teachers. Pilot studies inform advance warning on instrument's success / failure (McMillan \& Schumacher, 2001).

Table 1: $\quad$ Factor wise Reliability statistics

\begin{tabular}{|l|l|c|c|}
\hline Sr. no & Factors' names & N of Items & Cronbach's Alpha \\
\hline 1 & Communication & 5 & .801 \\
\hline 2 & Working environment & 5 & .769 \\
\hline 3 & Professional environment & 5 & .719 \\
\hline 4 & Quality of education & 6 & .761 \\
\hline 5 & Professional support & 5 & .794 \\
\hline 6 & Governors & 3 & .707 \\
\hline 7 & General & 1 & .699 \\
\hline
\end{tabular}

\subsection{Data Analysis and Interpretations}

The data were analyzed to answer the research questions one by one. The first question of the research was concerned with the perceptions of special education teachers regarding factors responsible for internal efficacy of their institution.

The mean and slandered deviation of teachers' responses has calculated and presented in the figure no.1.

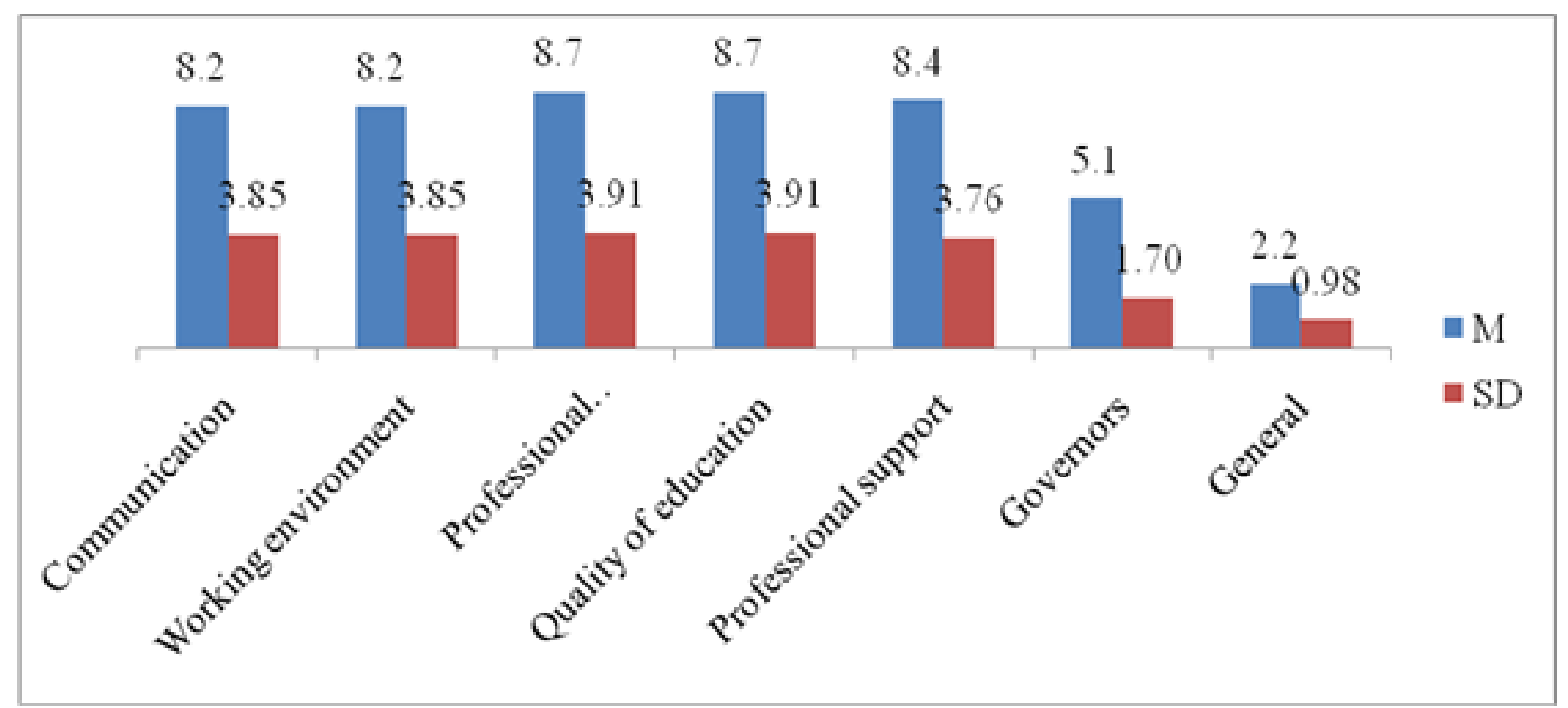

Figure No.2: Mean and Standard deviation of teachers' perceptions on determinents of internal efficacy in their institutions.

Figure No.2 shows the descreptive statistics(Mean \& SD) applied to measure teachers' perceptions working in public and private special education institutions of Lahore. Interpretation 
Review of Economics and Development Studies, Vol. 6 (4) 2020, 811 - 820

reveals that teachers' working in public and private special educational institutions perceieved communicative $(M=8.2, S D=3.85)$, working environment $(M=8.2, S D=3.85)$ professional environment $(M=8.7, S D=3.91)$, quality of education $(M=8.7, S D=3.91)$, professional support $(M=$ $8.4, S D=3.76)$ as strong determinents of internal efficacy as compared to institutionals' governors ( $M$ $=5.1, S D=1.70)$ and general aspects of the institutions $(M=2.2, S D=0.98)$ as determinents of special education institutions internal efficacy.

To answer the second question of the study, the data were analyzed through applying independent samples t-test. There were 30-items based on 3-point Likert type options. Data were analyzed in SPSS for the smooth analysis.

Table. No.2: Independent samples t-test on schools' type and teachers' perception on internal efficacy.

\begin{tabular}{|l|l|l|l|l|l|l|l|}
\hline School Type & $N$ & $M$ & $S D$ & $F$ & $d f$ & $T$ & $P$ \\
\hline Public & 93 & 66.430 & 15.696 & \multirow{2}{*}{48.49} & 198 & 16.521 & .05 \\
\hline Private & 107 & 34.7851 & 11.276 & & & \\
\hline
\end{tabular}

Table. No.2 shows the results of independent samples t-test applied to compare the perceptions of the teachers serving in public and private sector special education institutions on the internal efficacy of their respective institutions in District Lahore. Interpretation of the analyses reveals a statistically significant difference between the efficacy of public and private sector special education institutions as perceived by their teachers( $t=16.521, p<.05$. It is can be stated that public sector special education institutions have better internal efficacy $(M=66.430, S D=15.696)$ as compared to the private sector special education institutions $(M=34.785, S D=11.276)$.

To answer the third question of the study the independent sample t-test was applied on each factor related to internal efficacy as perceived by the teachers to see that either difference is existing and significant in all determinants of internal efficacy.

Table No. 2: Independent samples t-test on overall factors of schools' internal efficacy by schools' type

\begin{tabular}{|c|c|c|c|c|c|c|c|c|c|}
\hline No & Factors' names & Type & $N$ & $M$ & $S D$ & $F$ & $D f$ & $T$ & $P$ \\
\hline \multirow{2}{*}{1} & \multirow{2}{*}{ Communication } & Public & 93 & 10.968 & 3.552 & \multirow{2}{*}{84.442} & \multirow{2}{*}{198} & \multirow{2}{*}{12.756} & \multirow{2}{*}{.05} \\
\hline & & Private & 107 & 5.794 & 2.082 & & & & \\
\hline \multirow{2}{*}{2} & \multirow{2}{*}{ Working environment } & Public & 93 & 10.968 & 3.552 & \multirow{2}{*}{84.442} & \multirow{2}{*}{198} & \multirow{2}{*}{12.756} & \multirow{2}{*}{.05} \\
\hline & & Private & 107 & 5.794 & 2.082 & & & & \\
\hline \multirow[b]{2}{*}{3} & \multirow{2}{*}{ Professional environment } & Public & 93 & 11.968 & 2.708 & \multirow{2}{*}{35.080} & \multirow{2}{*}{198} & \multirow{2}{*}{17.605} & \multirow{2}{*}{.05} \\
\hline & & Private & 107 & 5.860 & 2.195 & & & & \\
\hline \multirow{2}{*}{4} & \multirow{2}{*}{ Quality of education } & Public & 93 & 11.968 & 2.708 & \multirow{2}{*}{35.080} & \multirow{2}{*}{198} & \multirow{2}{*}{17.605} & \multirow{2}{*}{.05} \\
\hline & & Private & 107 & 5.860 & 2.195 & & & & \\
\hline \multirow{2}{*}{5} & \multirow{2}{*}{ Professional support } & Public & 93 & 10.968 & 3.552 & \multirow{2}{*}{68.049} & \multirow{2}{*}{198} & \multirow{2}{*}{11.686} & \multirow{2}{*}{.05} \\
\hline & & Private & 107 & 6.168 & 2.174 & & & & \\
\hline \multirow{2}{*}{6} & \multirow{2}{*}{ Governors } & Public & 93 & 6.591 & 0.797 & \multirow{2}{*}{6.159} & \multirow{2}{*}{198} & \multirow{2}{*}{20.002} & \multirow{2}{*}{.05} \\
\hline & & Private & 107 & 3.804 & 1.120 & & & & \\
\hline \multirow{2}{*}{7} & Gene & Public & 93 & 3.000 & 0.000 & & 108 & 16517 & 05 \\
\hline & & Private & 107 & 1.505 & 0.873 & & & $10.5^{1 /}$ & .05 \\
\hline
\end{tabular}




\section{Review of Economics and Development Studies, Vol. 6 (4) 2020, $811-820$}

Table No.2 reflects that independent samples t-test was applied to compare the factors determines public and private special institutions' internal efficacy. Results of independent sample ttest showed significant difference between public and private special education teachers perceptions regarding the determinants factors of internal efficacy including communication, $t=12.756, p<.05$; working environment, $t=12.756, p<.05$; professional environment, $t=17.605, p<.05$; quality of education, $t=17.605, p<.05$; professional support, $t=11.686, p<.05$; governors, $t=20.002, p<.05$; general, $t=16.517, p<.05$. It is found that according to the teachers working in public sector special educational institutions, existing determinants of internal efficacy are better in their institutions as compared to the private sector institutions. The mean of communication is $(M=10.968, S D=3.552)$, working environment $(M=10.968, S D=3.552)$, professional environment $(M=11.968, S D=2.708)$, quality of education $(M=11.968, S D=2.708)$, professional support $(M=10.968, S D=3.552)$, governors $(M=6.591, S D=0.797)$, general $(M=3.000, S D=0.01)$ are higher as compared to the mean of teachers' working in private special education institutions on factors of communication $(M=$ $5.794, S D=2.082)$, working environment $(M=5.794, S D=2.082)$, professional environment $(M=$ $5.860, S D=2.195)$, quality of education $(M=5.860$, $S D=2.195)$, professional support $(M=6.168, S D=$ 2.174), governors $(M=3.804, S D=1.120)$ and the mean of general factors is $(M=1.505, S D=0.873)$.

\section{Discussion}

The perceptions of special education teachers on the internal efficacy of institutions are keenly measured through taking their response. According to many research studies teachers are an effective source to know the internal efficacy of academic institutions teaching experience (Adeyemi, 2007; Ayodele, 2005). Pakistani public sector educational institutions are categorized in general and special institutions (Awan \& Zia, 2015; Imran, 2008). Focusing the results of current study, teachers' teaching in public sectors special education institutions' rated the internal efficacy in their institutions higher as compared to the teachers serving in private sector special education institutions working in Lahore city. Government of Punjab has taking great interest in the special education institution since last two decades (Imran, 2008).

Whereas, private institutions are self-funded, and in certain cases they lacks resources and hire less qualified staff due to job insecurity. Results of present study established that public sector schools are internally more efficient in terms of communication, working and professional environment and professional support. These findings are in line with the findings of the study conducted by the (Akinwumiju, 1995; Babalola, 2005). Institutional internal efficacy demands teachers' higher qualification, heads visionary attitudes and better infrastructure and physical facilities (Weingarten, 2012) which is mostly present in public sector special education institutions. Furthermore results of current study have revealed that teachers of public sector special education institutions were more qualified due to better job securities, vibrant environment and schools infrastructure that congruent with the results of other studies (Adeyemi \& Adu, 2012). The study also highlighted better performance of students in public sector special education institution. The Students' better performance are due to teachers' pedagogical skill. Many other studies have highlighted the same points regarding the internal efficacy of academic institutions (Jaffer, 2000; Kerr, 2009; Ncube, 2004; Olatoun, 2012; Seiler et al., 2007).

\section{Conclusions}

Internal efficacy of special education institutions is an important element for the smooth running of schools. The study has tried to investigate the perceptions of special education teachers regarding the internal efficacy of public and private sector special education institutions. Due to the increased attention of the Government to the field of special education, the scenario of special education 
Review of Economics and Development Studies, Vol. 6 (4) 2020, 811 - 820

institutions has changed and reflected in the findings of this study. It is concluded that the internal efficacy of public sector special education institutions is much better as compared to the private sector special education institutions. Provision of funds, scholarships, job security and qualified teachers have increased the internal efficacy of the special education institutions. While, on the other hand, except few cases, private sector schools are deficient in highly qualified staff, job securities, teachers training and infrastructure.

\section{Recommendations of the study}

Following recommendations have made on the basis of research findings.

- Government should continue its efforts to strengthen the system of special education to further improve the internal efficacy of the special education institutions for the long run benefits of special students.

- There should be some support mechanism for the private sector special education institutions to uplift their internal efficacy for the larger interest of the persons with different disabilities living in this territory.

- The private sector special education institutions should improve their internal efficacy.

- The study may be conducted with the larger sample and adding some other stake holders of special education institutions in other districts to come up with more accurate findings.

\section{Limitations of the study}

Following were the limitations of the study.

- Due to the time and financial constraints, the special education institutions efficacy is estimated only by exploring the perceptions of 200 teachers. The other stake holders have not participated in the study.

- The data is collected only from one district.

\section{References}

Adeleke, F. F. (2011). Study of the internal efficiency of junior public and private secondary schools in Ekiti State, Nigeria”, Unpublished Master in Education Dissertation, University of Ado Ekiti, Nigeria.

Adeyemi, T. O. (2008). Organizational climate and teachers' job performance in primary schools in Ondo State, Nigeria: An analytical survey. Asian Journal of Information Technology, 7(4), 138-145.

Adeyemi, T. O. (2012). School variables and internal efficiency of secondary schools in Ondo State, Nigeria. Journal of Educational and Social Research, 2(3), 205-205.

Adeyemi1, T. O., \& Adu, E. T. (2012). Teachers' Quality and Internal Efficiency in Primary Schools in Ekiti State, Nigeria. American Journal of Economics, 2(5), 87-95 DOI: 10.5923/j.economics.20120205.04.

Ahmad, I., Rauf, M., Imdadullah, \& Zeb, A. (2012). Implementation gaps in educational policies of Pakistan: Critical analysis of problems and way forward. International Journal of Humanities and Social Science, 2(21), 240-245.

Akinloye, G. M., Adu, K. O., \& Adu, E. O. (2015). A comparative analysis of students' performance in economics in private and public secondary schools in Lagos State, Nigeria. Journal of Social Sciences, 44(3), 144-151. https://doi.org/10.1080/o9718923.2015.11893473

Akinwumiju, A. (1995). Educational planning statistics and models. Ibadan.

Awan, A. G., \& Zia, A. (2015). Comparative analysis of public and private educational institutions: A case study of district Vehari-Pakistan. Journal of Education and Practice, 6(16), 122-130. Ayodele, J. B. (2005). Fundamentals of systems analysis in education. Bolabay publications. 
Review of Economics and Development Studies, Vol. 6 (4) 2020, 811 - 820

Bless, C., \& Higson-Smith, C. (2000). Fundamentals of social research methods. Lusaka: Juta Education (Pty) Ltd.

Bryman, A. (2012). Social research methods (4th ed.). Oxford University Press.

Cohen, L., \& Duun, A. (2011). Research method in education, (7th Ed). London: Routledge.

Connelly, L. M. (2008). Pilot studies. Medsurg Nursing, 17(6), 411-412.

Creswell, J. W. (2014). Research design: Qualitative, quantitative and mixed methods approaches (2nd Ed.). Sage.

Dansey, R. S. (2004). Influence of teachers' empowerment on teachers organizational commitments. Teaching and Teachers Education Journal, 20(3), 277-299.

Dwaikat, N.Y. (2020). A comprehensive model for assessing the quality in higher education institutions. The TQM Journal. Available on https://doi.org/10.1108/TQM-06-2020-0133

Faize, F. A. (2011). Problems and prospects of science education at secondary level in Pakistan. Unpublished doctoral dissertation, faculty of social sciences, international Islamic university, Islamabad-Pakistan.

Galos, S., Aldridge, J.M.(2020). Relationships between learning environments and self-efficacy in primary schools and differing perceptions of at-risk students. Learning Environ Res. https://doi.org/10.1007/s10984-020-09323-0

Government of Pakistan (1959). Report of the commission on national education. Karachi: Government of Pakistan Press.

Government of Pakistan (1986 a). National policy for the education and rehabilitation of the disabled. Pakistan directorate general of special education, Islamabad.

Government of Pakistan (1986). National policy for rehabilitation of the disabled, Pakistan ministry of health, special education and social welfare, Islamabad.

Government of Pakistan (1999). The national policy for special education, Pakistan ministry of women development, social welfare and special education, Islamabad.

Government of Pakistan (2002). National policy for persons with disabilities, ministry of women development, social welfare and special education. Islamabad.

Hameed, A., Manzoor, A., (2016). Defeating inequalities in school access: A case of children with disabilities in Pakistan. Journal of Research in Special Educational Needs, 16(1), 345-350.

Haq, S. (2015). Public policy process in Pakistan: Key causes of public policies failures. Journal of Economic and Social Thought, 2(2), 127-131.

Hassan, M. Ul. (2019). Teachers' self-efficacy: Effective indicator towards students' success in medium of education perspective. Problems of Education in the 21st Century, 77(5), 667679.

Hassan, M. Ul., \& Akbar, R. A. (2020). Locus of control: Teachers' neglected attribute towards students' achievement scores in facing diverse socioeconomic status. Problems of Education in the 21st Century, 78(2), 282-300.

Imran, M. (2008). A comparative study of quality of education in public and private secondary schools of Punjab, Unpublished Doctoral Dissertation, Institute of education and research. Pir Mehr Ali Shah, Arid Agriculture University, Rawalpindi, Pakistan.

Iqbal, H. M., \& Mahmood, N. (2000). Science teacher education in Pakistan. In S. K. Abell (Ed.), Science teacher education: An international perspective, 75-92. Boston: Kluwer.

Jaffer, N. (2000). Problems of education in Pakistan. Royal Book Company: Karachi, Pakistan.

Kerr, T. (2009). The role of school principal. Titusville Area School District. Titusville: USA.

Khan, M. A., Hussain, A., Hussain, J., \& Khan, M. H. (2020). Effect of Performance Appraisal on Employees' Satisfaction: A Case Study of University of Peshawar, Khyber Pakhtunkhwa, Pakistan. Review of Applied Management \& Social Science, 3(2), 131-140. https://doi.org/10.47067/ramss.v3i2.40 
Review of Economics and Development Studies, Vol. 6 (4) 2020, 811 - 820

Lockheed, M. E., \& Hanushek, E. (1998). Improving educational efficiency in developing countries. What do we know? Compare: A Journal of Comparative and International Education, 18(1), 21-38. https://doi.org/10.1080/0305792880180103

McMillan, J. H., \& Schumacher, S. (2001). Research in education, (5th Ed.). Longman.

Ncube, J. N. (2004). Managing the Quality of Education in Zimbabwe: The Internal Efficiency of Rural Day Secondary Schools. Unpublished doctoral dissertation, University of South Africa, Zimbabwe.

Olatoun, A. A., (2012). Resource utilization and internal efficiency in Nigerian secondary schools: Implications for socio problems of education. International Journal of Sociology and Anthropology, 4(1), 23-30.

Olubor, R. O. (2004). A comparative analysis of the internal efficiency of public junior secondary education of two selected states in Nigeria. Journal of Educational Foundations and Managements, 4(1), 194-196.

Ramberg, J., Laftman, B.S., Almquist, Y.B., \&Modin, B.(2019).School effectiveness and students' perceptions of teachers caring: A multilevel study. Improving Schools,22(1),55-71.

Skaalvik, C. (2020). School principal self-efficacy for instructional leadership: relations with engagement, emotional exhaustion and motivation to quit. Social Psychology of Education, $1(2), 1-20$.

Seiler, M., Jo, A. G., Jones, J. T., Landy, B., Olds, S., \& Young, P. (2007). Indicators of efficiency \& effectiveness in elementary \& secondary education spending. Frankfort, Kentucky: Legislative Research Commission, USA.

Weingarten, R. (2012). The role of teachers in school improvement: Lessons from the field. Harvard Law \& Policy Review, 6(1), 9-38.

Yasmin, T., Nadeem, M., Siddique, G. K., \& Ali, M. S. Z. (2020). The Effect of Teachers' Language Speaking Anxiety on their Performance in English. Review of Education, Administration \& LAW, 3(2), 285-291. https://doi.org/10.47067/real.v3i2.63

Yunas, M. (2014). Developing a framework for promoting internal efficiency of secondary schools, Unpublished Doctoral Dissertation, Faculty of arts, social sciences and education, Sarhad University of Science and Information Technology, Peshawar-Pakistan. 